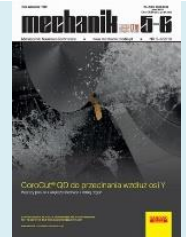

Authors: Magdalena Szutkowska, Marek Boniecki, Marcin Podsiadło, Andrzej Kalinka

Title of article: „Właściwości mechaniczne kompozytów narzędziowych z tlenku glinu, wzmacnianych węglikoazotkiem tytanu” ("Mechanical properties of titanium carbonitride reinforced alumina tool composites")

Mechanik, Vol. 91, No. 5-6 (2018): pages 438-442

DOI: https://doi.org/10.17814/mechanik.2018.5-6.55

\title{
Mechanical properties of titanium carbonitride reinforced alumina tool composites
}

\author{
Właściwości mechaniczne kompozytów narzędziowych \\ z tlenku glinu, wzmacnianych węglikoazotkiem tytanu
}

MAGDALENA SZUTKOWSKA

MAREK BONIECKI

MARCIN PODSIADLO

ANDRZEJ KALINKA *

The present study reports mechanical properties obtained by reinforcing alumina composites with $\mathrm{Ti}(\mathrm{C}, \mathrm{N})$ in amount $\mathbf{3 0} \mathrm{wt}$ \% prepared on the basis micro and nanoscale trade powders. The pressureless sintering PS in a vacuum and SPS method of sintering were used. Vickers hardness, density, Young modulus, wear resistance were evaluated. Fracture toughness (KIC) at ambient and elevated temperatures up to 1073 $\mathrm{K}$, characteristic for tool work was measured. Physical and mechanical properties of the composites $\mathrm{Al2O} / \mathrm{Ti}(\mathrm{C}, \mathrm{N}) / \mathrm{ZrO} 2$ based on the powders in microscale were compared with composites containing nanoscale powders in a range from 17 to 36 wt.\%. Tested composites with nanoscale powders content reveal

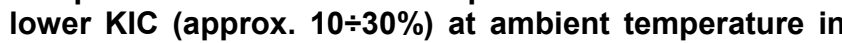
comparison to composites based on powders in microscale. However, in the elevated temperatures their fracture toughness increases up to $30 \%$. The observation of the microstructure of tested composites was carried out using scanning electron microscopy.

KEYWORDS: ceramic composites Al2O3/Ti(C,N)/ZrO2, nanopowders, micropowders, reaction sintering SPS, pressureless sintering PS, fracture toughness Ceramic composites based on alumina, used for cutting tools

Metalworking tools and high-speed steel still dominate in metal machining, but for special purposes (for high-speed cutting and feed machining), ceramic tool materials based on aluminum oxide are used. According to Dedalus Consulting New York on the global market in 2013, materials used for the production of sintered carbide cutting tools accounted for $53 \%$, and high-speed steels only $20 \%$ (fig. 1) [1].

The share of ceramic materials was $19 \%$, but the forecasts for 2018 are even more optimistic and assume a high growth rate of hard and super-hard cutting materials, including PcBN and PCD ceramics [2].

\footnotetext{
* Dr hab. inż. prof. IZTW Magdalena Szutkowska (szutkows@ios.krakow.pl), mgr inż. Marcin Podsiadło (marcin.podsiadlo@ios.krakow.pl), mgr inż. Andrzej Kalinka (andrzej.kalinka@ios.krakow.pl) - Instytut Zaawansowanych Technologii Wytwarzania; dr Marek Bonieck (marek.boniecki@itme.edu.pl) - Instytut Technologii Materiałów Elektronicznych
}

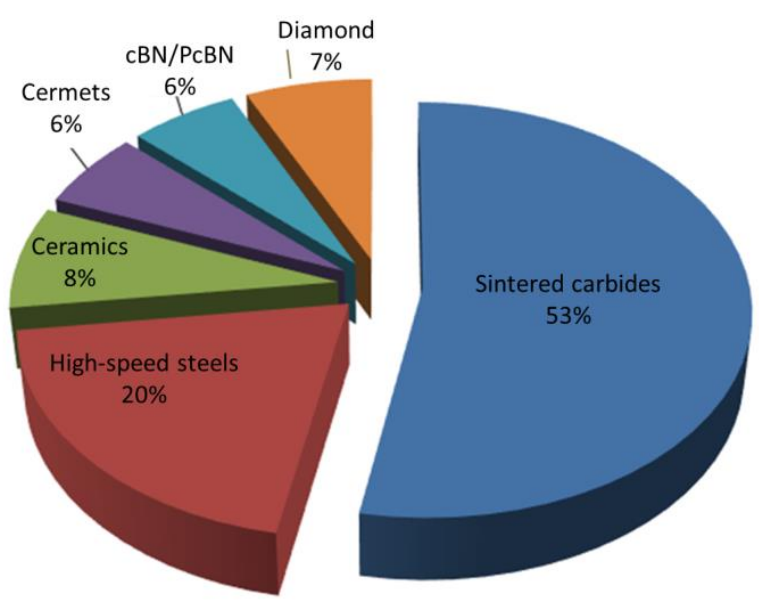

Fig. 1. Share of materials used for cutting tools on the global market in 2013 [1]

After functional materials intended for broadly defined electronics devices, the most important group of ceramic materials are advanced ceramic construction materials: nitride, silicon carbide, aluminum oxide and zirconium oxide. Due to their properties, they are suitable for working in difficult operating conditions.

Sintered ceramic products, resistant to wear, include, among others tool cutting edges for machining. Near the cutting edge of the tool, high shear stresses arise in the workpiece, therefore the material from which the blade is made must be very resistant to plastic deformation and have a high hardness. During the operation of the cutting tool's blade there are rapid changes in temperature, thus its resistance to thermal shocks is also important (the blade should be characterized by high thermal conductivity and low coefficient of thermal expansion). This is especially important in the case of machining in a non-continuous manner, when the cutting tool's blade is being cooled down temporarily. 
Although ceramic construction materials have very good functional properties (thermal and chemical durability, low density, high hardness, stiffness, wear resistance and good mechanical strength), the very high reliability of these materials limits their use in long-term loads and shocks heat. Ceramics are characterized by low resistance to brittle fracture and a large dispersion of mechanical properties, expressed by a small value of the Weibull module [3]. Materials with a more complex structure - composites - have much better properties. For their production, the second phase dispersion technique is used with a coefficient of thermal expansion significantly differing from the matrix material coefficient.

As a result of the modification of the microstructure of the ceramics, by introducing the second phase of alumina, the useful properties of the material change (mechanical strength or resistance to sudden changes in temperature). On the basis of the research it was found that ceramic composites in which the matrix of alumina is dispersal strengthened with a ceramic phase in the form of TiC, TiN, $\mathrm{ZrO}_{2}, \mathrm{WC}, \mathrm{NbC}, \mathrm{Ti}(\mathrm{C}, \mathrm{N}), \mathrm{SiC}$ or $\mathrm{TiB}_{2}$, are characterized by high hardness, resistance to chemical wear and inertness, and have higher mechanical strength and porosity compared to aluminum oxide [4-6].

Some authors [7] believe that $\mathrm{Ti}(\mathrm{C}, \mathrm{N})$ is the ideal phase reinforcing the alumina matrix, because as a solid solution TiC and TiN has high hardness and very good wear resistance. The solid solution $\mathrm{Ti}(\mathrm{C}, \mathrm{N})$ has both high hardness characteristic for $\mathrm{TiC}$ and high ductility comparable to TiN [8]. Due to their properties, ceramic composites based on alumina can work in difficult conditions, typical for many technologies, such as machining. These materials have the ability to maintain good mechanical properties at high temperature, achieving even $1173 \mathrm{~K}$ (fig. 2) under the working conditions of the tool [9].

A variety of sintering technologies are used to produce ceramic tool composites with improved mechanical properties [10-12]:

- non-pressure sintering - PS (pressureless),

- hot pressing - HP (hot pressing),

- hot isostatic pressing - HIP (hot isostatic pressing),

- microwave sintering - MW (microwave),

- reactionary sintering - SPS (spark plasma sintering).

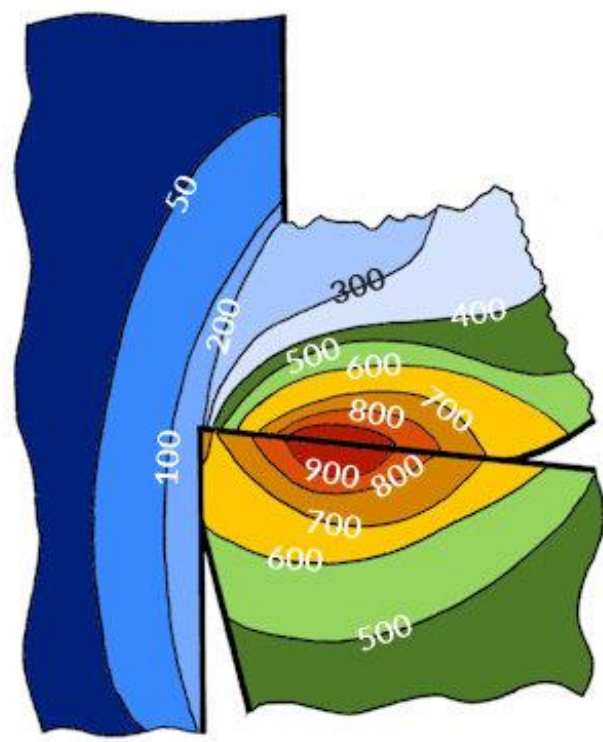

Fig. 2. Temperature distribution on the tool tip [9]

Non-pressure sintering of high-density ceramic materials requires a low heating rate, high sintering temperature and long life time, which significantly increases the cost of the process. Due to the SPS reaction method, based on the simultaneous application of pressure and current pulses, very good mechanical properties of ceramic composites are obtained, while at the same time ensuring energy-saving process.

The article focuses on the comparison of physical and mechanical properties of $\mathrm{Al}_{2} \mathrm{O}_{3} / \mathrm{Ti}(\mathrm{C}, \mathrm{N}) / \mathrm{ZrO}_{2}$ non-pressure sintered (PS) and in reaction (SPS) ceramic composites. Mixed powders with micrometric and nanometric particle size were used to make ceramic composites based on alumina reinforced $\mathrm{Ti}(\mathrm{C}, \mathrm{N})$. The influence of powders with nanometric particle sizes on selected physical and mechanical properties determining the usefulness of ceramic material on cutting tools was determined.

The research conducted so far shows that the introduction of nano-size carbide phases into tool materials based on aluminum oxide does not increase the fracture toughness at room temperature [13]. Typically, the KIC fracture toughness determined for ambient temperature is taken as the basic criterion for the fragility assessment. Measurements at a temperature close to the one obtained during work are performed sporadically, due to the necessity of using specialized equipment and labor-intensive measurements. Knowledge of fracture toughness of ceramic composites at elevated temperature, typical for the working conditions of the tool, will allow for a more precise selection of the scope of their application.

\section{Materials and research methodology}

A powder with a content of $99.8 \%$ by weight of $\alpha-\mathrm{Al}_{2} \mathrm{O}_{3}$, with a particle size below $0.5 \mu \mathrm{m}$, of the grade A16SG, produced by ALCOA (USA), and nanometric sizes of $40 \mathrm{~nm}$ particles, occurring in the form of agglomerates of approx. $150 \mathrm{~nm}$ and $99.8 \%$ purity, manufactured by Inframat Advanced Materials (USA). Titanium carbonitride Ti (C, N) $30 / 70$, manufactured by H.C. Starck (Germany), in the form of a powder with micrometric and nanometric particle sizes of approx. $40 \mathrm{~nm}$, produced by Neomat (Lithuania), was an addition to the base alumina powder. $\mathrm{ZrO}_{2}$ powder in micrometer size, produced by Fluka (Switzerland), and nanometer size 30 $\div 60 \mathrm{~nm}$, produced by Inframet Advanced Materials (USA), was added to the base powder mix. To prevent the growth of alumina grain during sintering, small amounts of $99.5 \%$ magnesium oxide $\mathrm{MgO}$ powder, manufactured by Inframet Advanced Materials (USA), were used. The blends were made on the basis of powders $\left(\mathrm{Al}_{2} \mathrm{O}_{3}\right.$ $+\mathrm{MgO}$ ) in an amount of $68 \%$ by weight, with additions of titanium carbonitride in the amount of $30 \%$ by weight and zirconium oxide in the amount of $2 \%$ by weight. The initial quantitative and phase compositions of individual composites are included in the tab. I.

TABLE I. Base quantitative and phase compositions of the tested composites

\begin{tabular}{|c|c|c|c|c|c|c|c|}
\hline \multirow[t]{3}{*}{ Samples } & \multicolumn{6}{|c|}{$\begin{array}{l}\text { Phase composition of the mixture,\% } \\
\text { by weight }\end{array}$} & \multirow{3}{*}{$\begin{array}{c}\text { Share of } \\
\text { nanopowders, } \\
\text { [\%] }\end{array}$} \\
\hline & \multicolumn{2}{|c|}{$\mathrm{Al}_{2} \mathrm{O}_{3}+\mathrm{MgO}$} & \multicolumn{2}{|c|}{$\operatorname{Ti}(\mathrm{C}, \mathrm{N})$} & \multicolumn{2}{|c|}{$\mathrm{ZrO}_{2}{ }^{(\mathrm{m})}$} & \\
\hline & $\mu \mathrm{m}$ & $\mathrm{nm}$ & $\mu \mathrm{m}$ & $\mathrm{nm}$ & $\mu \mathrm{m}$ & $\mathrm{nm}$ & \\
\hline $\mathrm{C} 1 / \mathrm{C} 4$ & 68 & - & 30 & - & 2 & - & 0 \\
\hline $\mathrm{C} 2$ & 58 & 10 & 25 & 5 & - & 2 & 17 \\
\hline $\mathrm{C} 3$ & 34 & 34 & 30 & - & - & 2 & 36 \\
\hline
\end{tabular}

Ceramic composites based on aluminum oxide $\mathrm{Al}_{2} \mathrm{O}_{3} / \mathrm{Ti}(\mathrm{C}, \mathrm{N})$ with the addition of $\mathrm{ZrO}_{2}$, with different sizes of starting powders, were sintered in a vacuum under the same conditions. Composite based on powders with a micrometer size is marked with the symbol $\mathrm{C} 1$, and composites based on mixed powders of micrometric and nanometric sizes in quantities of 17 and $36 \%$ by weight symbols C2 and C3 (tab. I). A sample made of a mixture of micrometer sized powders and the same composition as $\mathrm{C} 1$ 
sample was sintered by the SPS method and marked with C4 symbol. Samples with dimensions of $5.5 \mathrm{~mm} \times 3.0 \mathrm{~mm} \times$ $35.0 \mathrm{~mm}$ were pre-formed in steel dies at $100 \mathrm{MPa}$, and then were densified isostatically at a pressure of $200 \mathrm{MPa}$. The compacts were sintered for one hour in a HTK8 G22 GERO furnace under vacuum to $1973 \mathrm{~K}$. Powder micrometer-sized (C4) samples were subjected to SPS sintering using current pulses and the FCT HP D5. The samples were sintered for 10 minutes in argon at $35 \mathrm{MPa}$ and $1923 \mathrm{~K}$. The tests included:

- determination of density by saturation in a vacuum - in accordance with PN-EN 623-2-2001 [14],

- measurement of Vickers hardness with a load of $294.3 \mathrm{~N}$ using the Future-Tech Corp. FLC-50V digital multifunction tester,

- measurement of the Young's modulus based on the velocity of transverse and longitudinal wave propagation, using the Panametrix EPOCH III ultrasonic flaw detector, equipped with broadband heads emitting longitudinal and transverse waves.

Measurements of velocity of propagation of longitudinal ultrasonic waves were made in any directions. The Young's modulus was determined according to the following formula:

$$
E=\rho C_{\mathrm{T}}^{2} \frac{3 C_{\mathrm{L}}^{2}-4 C_{\mathrm{T}}^{2}}{C_{\mathrm{L}}^{2}-C_{\mathrm{T}}^{2}}
$$

where: $E$ - Young's modulus, $\rho$ - apparent density, $C_{\mathrm{L}}$ longitudinal wave velocity, $C_{\mathrm{T}}$ - transverse wave velocity.

Resistance to abrasive wear was determined according to its own methodology, based on measuring the velocity of mass loss of the sample during its abrasion on the rotating disc with the SiC80 embankment. Samples with dimensions of $4.8 \mathrm{~mm} \times 4.8 \mathrm{~mm} \times 13 \mathrm{~mm}$ were used, which under a constant load of $29.4 \mathrm{~N}$ were spiraling on the disk. The duration of the test was $1 / 60 \mathrm{~h}$, which corresponds to 30 revolutions of the disc.

The grinding distance was $10.3 \mathrm{~m}$. The velocity loss velocity $V_{\mathrm{n}}$ was determined according to the formula:

$$
V_{\mathrm{n}}=\frac{1000 \cdot \Delta m}{\rho_{\mathrm{P}} \cdot F \cdot T} \mu \mathrm{m} / \mathrm{h}
$$

where: $\rho_{\mathrm{P}}$ - apparent density of the sample in $\mathrm{g} / \mathrm{cm}^{3}, T$ working time of the sample in $\mathrm{h}, F$ - contact surface of the sample in $\mathrm{mm}^{2}, \Delta m$ - absolute weight use of the sample in $\mathrm{mg}$ at constant parameters.

The fracture toughness $K_{\mathrm{IC}}$ was determined from a threepoint test of static bending of SENB type specimens, with a notch cut in a mechanical manner by means of diamondtipped saw blades. Half of the length of the samples in the shape of the belle with dimensions of $1.5 \mathrm{~mm} \times 4.0 \mathrm{~mm} \times$ $30.0 \mathrm{~mm}$, saws were cut with a $200 \mu \mathrm{m}$ thick diamond chip to a depth of $900 \mu \mathrm{m}$. At the bottom of the notch a $25 \mu \mathrm{m}$ thick incision was made to a depth of $200 \mu \mathrm{m}$. The notches obtained in this way were characterized by a sharp end which initiated the crack. The shape of the SENB type sample used to determine fracture toughness is shown in fig. 3 .

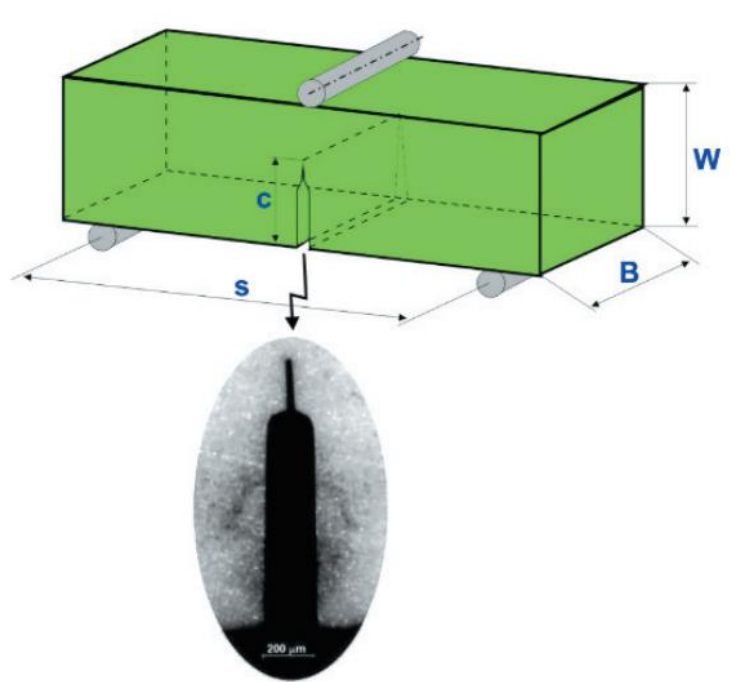

Fig. 3. Shape of the SENB type sample used to determine fracture toughness using the conventional method

The formulas $[15,16]$ were used to determine the fracture toughness:

$$
K_{\mathrm{IC}}=1,5 \frac{P_{\mathrm{c}} S}{W^{2} B} Y c^{1 / 2}
$$

$$
Y=\frac{\sqrt{\pi}}{(1-\alpha)^{\frac{3}{2}}}\left[0,3738 \alpha+(1-\alpha) \sum_{i, j=0}^{4} A_{i j} \alpha^{i}\left(\frac{W}{S}\right)^{j}\right]
$$

where: $P_{\mathrm{c}}$ - load, $S$ - spacing of supports, $W$ - width of the sample, $B$ - thickness of the sample, $c$ - depth of the notch, $\alpha=c / W, A i j$ - coefficients given by Fett [16].

Measurements of fracture toughness were carried out on a ZWICK 1446 testing machine with a $1 \mathrm{kN}$ head. Threepoint bending (3PB) of samples was used, with a deformation speed of $1 \mathrm{~mm} / \mathrm{min}$. Attempts to bend samples with a notch at elevated temperature of $873 \mathrm{~K}$ and $1073 \mathrm{~K}$ were made at the Institute of Electronic Materials Technology, on a stand assembled in a heating device placed on a special boom in a testing machine (fig. 4).

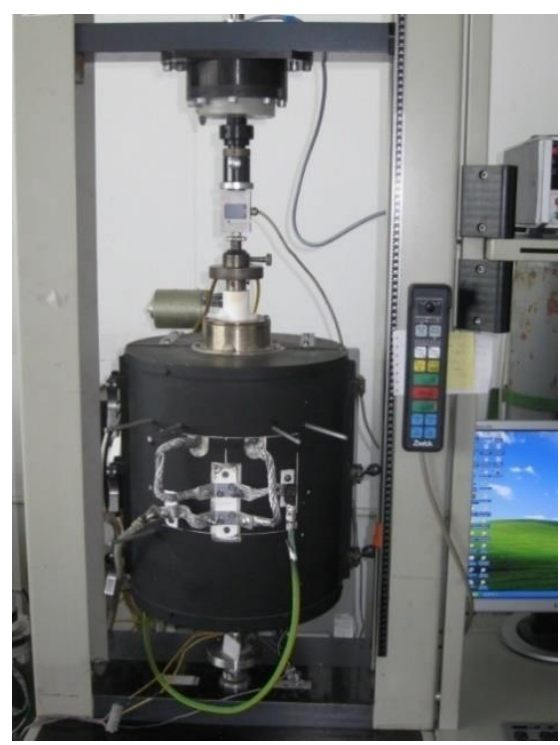

Fig. 4. Stand for measurements of fracture toughness at elevated temperature 
The coefficient of friction was determined by means of a universal mechanical tester type UMT-2T in the Ball-OnDisc system, using balls made of $100 \mathrm{Cr} 6$ bearing steel with a diameter of $3 \mathrm{~mm}$. The microstructure of the samples was observed on a Japanese scanning microscope - JEOL JSM 6064. The phase composition of composites based on alumina was identified using an X-ray diffractometer manufactured by PANalytical model Empyrean Series 2, equipped with two detectors: PIXcel3D and proportional xenon.

\section{Results}

The results obtained from the measurements of selected physical and mechanical properties of the tested $\mathrm{Al}_{2} \mathrm{O}_{3} / \mathrm{Ti}(\mathrm{C}, \mathrm{N}) / \mathrm{ZrO}_{2}$ composites are presented in the tab. II.

\section{TABLE II. Physical and mechanical properties of $\mathrm{Al}_{2} \mathrm{O}_{3} / \mathrm{Ti}(\mathrm{C}, \mathrm{N}) / \mathrm{ZrO}_{2}$ composites}

\begin{tabular}{|c|c|c|c|c|c|}
\hline $\begin{array}{c}\text { Sample desig- } \\
\text { nation }\end{array}$ & $\begin{array}{c}\text { Density }{ } \rho, \\
g^{\prime} / \mathrm{cm}^{3}\end{array}$ & $\begin{array}{l}\text { Vickers hard- } \\
\text { ness HV30, } \\
\text { GPa }\end{array}$ & $\begin{array}{l}\text { Young's modu- } \\
\text { lus } E, \mathrm{GPa}\end{array}$ & $\begin{array}{c}\text { Fracture toughness } \\
K_{\mathrm{IC}} \text { at temperature } 293 \mathrm{~K} \text {, } \\
\mathrm{MPa} \cdot \mathrm{m}^{1 / 2}\end{array}$ & $\begin{array}{c}\text { Mass loss } \\
\text { velocity } V_{\mathrm{n}} \cdot 10^{3} \\
\mu \mathrm{m} / \mathrm{h}\end{array}$ \\
\hline C1 & 4,18 & 17,5 & 385 & 4,22 & 4,9 \\
\hline $\mathrm{C} 2$ & 4,03 & 15,2 & 345 & 3,35 & 20,5 \\
\hline C3 & 3,90 & 12,4 & 310 & 3,43 & 41,5 \\
\hline $\mathrm{C} 4$ & 4,29 & 17,0 & 420 & 4,13 & 5,0 \\
\hline
\end{tabular}

The results obtained from measurements of physical and mechanical properties for $\mathrm{Al}_{2} \mathrm{O}_{3} / \mathrm{Ti}(\mathrm{C}, \mathrm{N}) / \mathrm{ZrO}_{2}$ type composites based on micrometer $\mathrm{C} 1$ (sintered free sintered) and C4 (sintered SPS) powders have similar values. The density ranges from $4.18 \mathrm{~g} / \mathrm{cm}^{3}$ to $4.29 \mathrm{~g} / \mathrm{cm}^{3}$, Vickers hardness - from 17.0 to $17.5 \mathrm{HV} 30$, Young's modulus - from $385 \mathrm{GPa}$ to $420 \mathrm{GPa}$, and fracture toughness determined at $293 \mathrm{~K}$ - from $4.13 \mathrm{MPa} \cdot \mathrm{m}^{1 / 2}$ to $4.22 \mathrm{MPa} \cdot \mathrm{m}^{1 / 2}$, and the rate of weight loss - from $4.9 \cdot 103$ to $5.0 \cdot 103 \mu \mathrm{m} / \mathrm{h}$. The share of mixed powders of micrometric and nanometric sizes, marked with the symbols C2 and C3, adversely affects the physical and mechanical properties determined at room temperature.

These samples are characterized by lower physical and mechanical properties compared to samples based on micrometer sized powders. Differences in values for Vickers hardness, Young's modulus and fracture toughness range from $10 \%$ to $30 \%$. A significant increase in the weight loss rate of samples based on a mixed proportion of nanometric and micrometric powders indicates their low wear resistance. In contrast, $\mathrm{KIC}$ fracture toughness values in the temperature range from $873 \mathrm{~K}$ to $1273 \mathrm{~K}$ increase by approx. 30\% for samples marked with $\mathrm{C} 2$ and $\mathrm{C} 3$ symbols, based on mixed powders of nanometric and micrometric sizes (fig. 5). Such relationships are not observed for samples made of powders with micrometric size, marked $\mathrm{C} 1$ and C4. The value of the coefficient of friction for samples based on micrometer sized powders, designated C4, is 0.31 and increases to 0.45 for samples based on mixed powders of nanometric and micrometric sizes, designated $\mathrm{C} 2$.

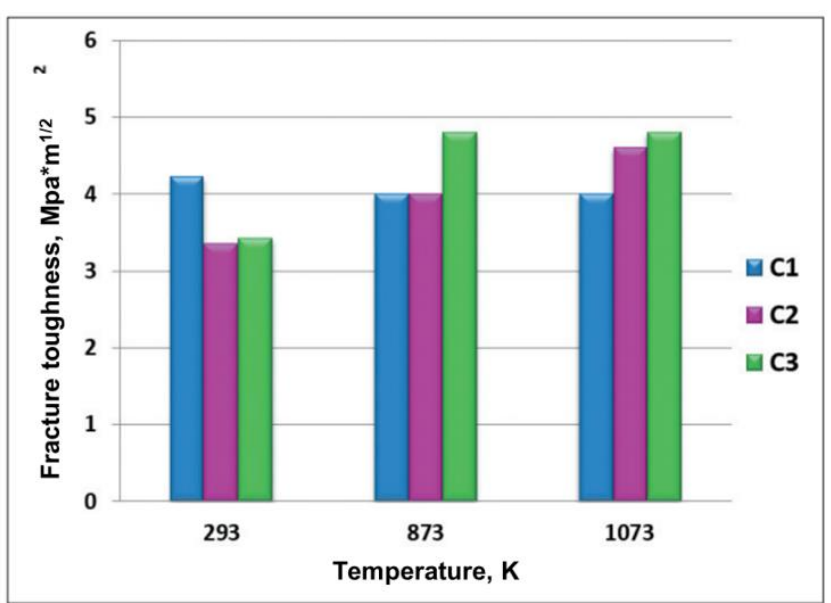

Fig. 5. Fracture toughness of composites with alumina matrix at room temperature and elevated temperature
Observations of microstructure of breakthroughs of $\mathrm{Al}_{2} \mathrm{O}_{3} / \mathrm{Ti}(\mathrm{C}, \mathrm{N}) / \mathrm{ZrO}_{2}$ composites based on micrometer (C1) and mixed (micrometer and nanometer) powders (C3) are shown in fig. 6.
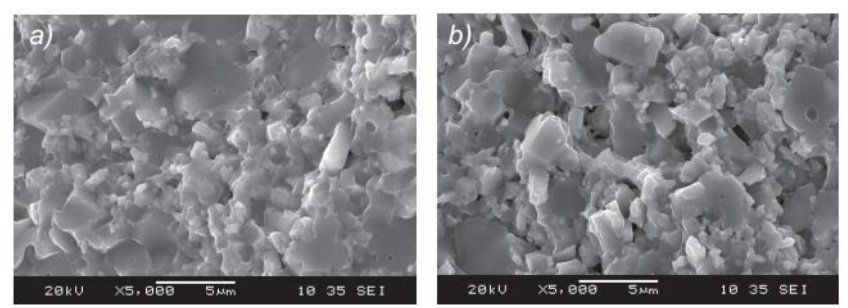

Fig. 6. Microstructure of fractures of tested composites for powderbased samples: a) micrometric (C1), b) mixed - micrometric and nanometric (C3)

Breakthroughs in the tested composites are mixed - both trans-crystalline and inter-granular. Based on observations of the microstructure of $\mathrm{Al}_{2} \mathrm{O}_{3} / \mathrm{Ti}(\mathrm{C}, \mathrm{N}) / \mathrm{ZrO}_{2}$ ceramic composites, point chemical composition analysis (EDS) and quantitative analysis of the percentage of elements in the studied micro-regions, the following phases were found: $\mathrm{TiC}, \mathrm{TiN}, \mathrm{ZrO}_{2}$ and $\mathrm{Al}_{2} \mathrm{O}_{3}$ (fig. 7).

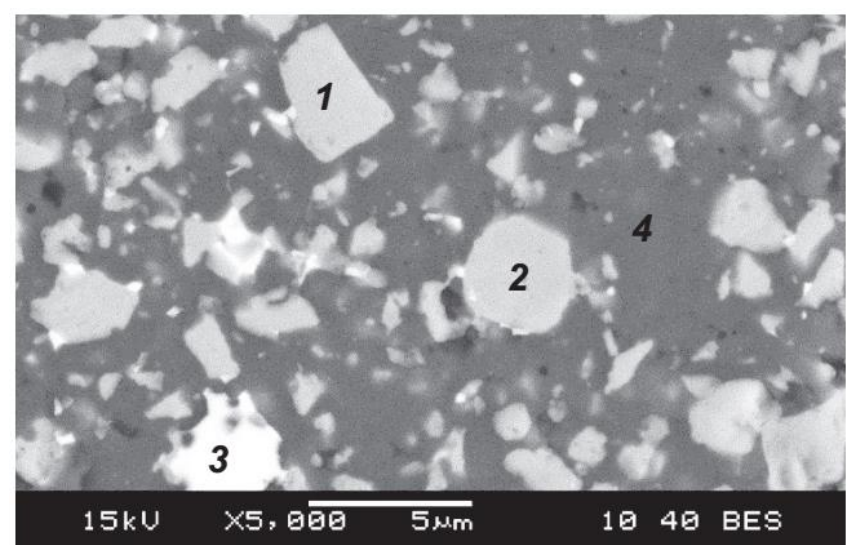

Fig. 7. Microstructure of $\mathrm{Al}_{2} \mathrm{O}_{3} / \mathrm{Ti}(\mathrm{C}, \mathrm{N}) / \mathrm{ZrO}_{2}$ composite (sample $\mathrm{C} 4$ ): 1 - TiC, 2 - TiN, $3-\mathrm{ZrO}_{2}, 4-\mathrm{Al}_{2} \mathrm{O}_{3}$

X-ray diffraction of $\mathrm{Al}_{2} \mathrm{O}_{3} / \mathrm{Ti}(\mathrm{C}, \mathrm{N}) / \mathrm{ZrO}_{2}$ composites revealed the occurrence (fig. 8):

- aluminum oxide in the range of 71 to $75 \%$ by weight,

- $\mathrm{Ti}(\mathrm{C}, \mathrm{N})$ ranging from 23 to $28 \%$ by mass,

- $\mathrm{ZrO}_{2}$ in an amount of 1 to $2 \%$ by weight.

The X-ray diffraction pattern of $\mathrm{Al}_{2} \mathrm{O}_{3} / \mathrm{Ti}(\mathrm{C}, \mathrm{N}) / \mathrm{ZrO}_{2}$ composite with marked phases for samples $\mathrm{C} 1$ and $\mathrm{C} 4$ is shown in fig. 8. 


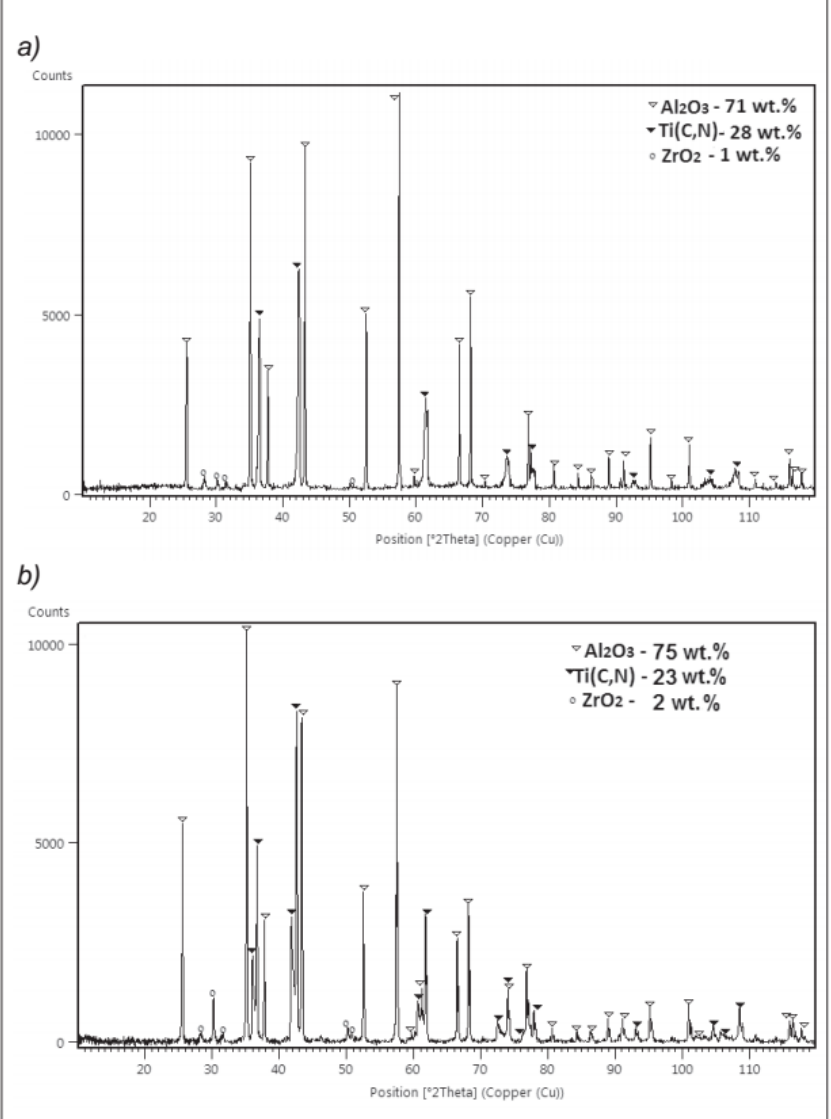

Fig. 8. X-ray diffractogram with marked phases of $\mathrm{Al}_{2} \mathrm{O}_{3} / \mathrm{Ti}(\mathrm{C}, \mathrm{N}) / \mathrm{ZrO}_{2}$ composite for micrometer-sintered powders: a) non-pressure PS $(\mathrm{C} 1)$, b) reaction SPS (C4)

Based on the analysis of the test results, it was found that a significant proportion of nanometric powders in the amount of up to $36 \%$ (mainly $\mathrm{Al}_{2} \mathrm{O}_{3}$ ), introduced into mixtures with $\mathrm{Al}_{2} \mathrm{O}_{3}-\mathrm{Ti}(\mathrm{C}, \mathrm{N})-\mathrm{ZrO}_{2}$ composition, is unfavorable, because it reduces the physical and mechanical properties of the sinters. For comparative purposes, the same parameters were used for sintering $\mathrm{Al}_{2} \mathrm{O}_{3} / \mathrm{Ti}(\mathrm{C}, \mathrm{N}) / \mathrm{ZrO}_{2}$ composites. Currently, work is under way to determine the dependence of the properties of composites on the number and phase composition of powders with nanometric particle sizes using modern sintering methods, using pressure.

\section{Conclusions}

$\mathrm{Al}_{2} \mathrm{O}_{3} / \mathrm{Ti}(\mathrm{C}, \mathrm{N}) / \mathrm{ZrO}_{2}$ composites based on alumina, $30 \%$ by weight $\mathrm{Ti}(\mathrm{C}, \mathrm{N})$ and $2 \%$ by weight $\mathrm{ZrO}_{2}$, based on micrometric particle size, sintered non-pressure sintered (PS) and in reaction (SPS), are characterized by the highest and similar physical and mechanical properties. The proportion of powders with mixed particle sizes (nanometric and micrometric), introduced in an amount of 17 to $36 \%$ to mixtures with the composition $\mathrm{Al}_{2} \mathrm{O}_{3}-\mathrm{Ti}(\mathrm{C}, \mathrm{N})-\mathrm{ZrO}_{2}$, adversely affects their physical and mechanical properties (reduces them by $10 \div 30 \%$ ). A significant increase in the weight loss rate of these samples indicates their low wear resistance. However, the value of fracture toughness in the temperature range $873 \div 1273 \mathrm{~K}$ increases by approx. $30 \%$ in the case of samples based on mixed powders with nanometric and micrometric particle sizes.

\section{REFERENCES}

1. N.N. Cutting Tools. New York: Dedalus Consulting, 2014, www. edalusconsulting.com.

2. Bobzin K. "High-performance coatings for cutting tools". CIRP J. Manuf. Sci. and Tech. 18 (2017): pp. 1-9.

3. Pampuch R. „Kompozyty Ceramiczne”. Kompozyty (Composites). 2 (2002): pp. 3-16.

4. Yin Z., Huanda Ch., Zoua B., Liua H., Zhua H., Wang J. "Preparation and characterization of $\mathrm{Al}_{2} \mathrm{O}_{3} /$ TiC micro-nano-ceramic tool materials”. Ceramics International. 39, 4 (2013): pp. 4253-4262.

5. Acchar W., Cairob C.A. "The influence of (Ti,W) $\mathrm{C}$ and $\mathrm{NbC}$ on the mechanical behavior of alumina". Materials Research. 9, 2 (2006): pp. 171-176.

6. Song S.-X., Ai X., Zhao J., Huang Ch.-Z. " $\mathrm{Al}_{2} \mathrm{O}_{3} / \mathrm{Ti}\left(\mathrm{C}_{0.3} \mathrm{~N}_{0.7}\right)$ cutting tool material". Materials Science Engineering. A-Structure. 356 (2002):pp. 43-47.

7. Wu F., Chen T., Wang H., Liu D. "Effect of Mo on Microstructures and Wear Properties of In Situ Synthesized Ti(C,N)/Ni-Based Composite Coatings by Laser Cladding". Materials. 10, 9 (2017): pp. 112.

8. Peng Y., Miao H.Z., Peng Z.J. "Development of TiCN-based cermets: mechanical properties and wear mechanism". International Journal of Refractory Metals and Hard Materials. 39 (2013):pp. 7889.

9. Jemielniak K. „Obróbka skrawaniem”. Warszawa: Oficyna Wydawnicza Politechniki Warszawskiej, 1998.

10. Zengbin Y., Juntang Y., Zhenhua W., Hanpeng H., Yu Ch., Xiaoqiu $\mathrm{H}$. "Preparation and properties of an $\mathrm{Al}_{2} \mathrm{O}_{3} / \mathrm{Ti}(\mathrm{C}, \mathrm{N})$ micro-nanocomposite ceramic tool material by microwave sintering". Ceramics International. 42 (2016): pp. 4099-4106.

11. Xiong H., Zhi You Li., Gan X., Chai L. "Morphology evolution of TiC-based cermets via different sintering schedules". Ceramics International. 43 (2017): pp. 5805-5812.

12. Zheng Y., Wang S., You M., Tan H., Xiong W. "Fabrication of nanocomposite $\mathrm{Ti}(\mathrm{C}, \mathrm{N})$-based cermet by spark plasma sintering". Materials Chemistry and Physics. 92 (2005): pp. 64-70.

13. Szutkowska M., Smuk B., Boniecki M. "Titanium Carbide Reinforced Composite Tool Ceramics Based on Alumina". Advances in Science and Technology. 65 (2010): pp. 50-55.

14. PN-EN 623-2-2001. Techniczna ceramika zaawansowana. Ceramika monolityczna. Właściwości ogólne i strukturalne. Część 2: Oznaczanie gęstości i porowatości.

15. PN-EN ISO 15732:2005(U). Ceramika wysokiej jakości (ceramika zaawansowana, techniczna ceramika zaawansowana) - Metoda badania odporności na kruche pękanie ceramiki monolitycznej w temperaturze pokojowej metodą belki wstępnie pękniętej z jednej strony (SEPB).

16. Fett T., Munz D. "Subcritical crack growth of macrocracks in alumina with R-curve behavior". Journal of American Ceramic Society. 75, 4 (1992): pp. 958-963.

Translation of scientific articles, their computer composition and publishing them on the website www.mechanik.media.pl by original articles in Polish is a task financed from the funds of the Ministry of Science and Higher Education designated for dissemination of science. 